\title{
Female Reproductive Factors and Differentiated Thyroid Cancer
}

\author{
Mariacarla Moleti*, Giacomo Sturniolo, Maria Di Mauro, Marco Russo \\ and Francesco Vermiglio \\ Unit of Endocrinology, Department of Clinical and Experimental Medicine, University of Messina, Messina, Italy
}

\section{OPEN ACCESS}

Edited by:

Antonino Belfiore,

Magna Græcia University, Italy

Reviewed by:

Dario Giuffrida,

Istituto Oncologico

del Mediterraneo, Italy

Stefania Catalano,

University of Calabria, Italy

${ }^{*}$ Correspondence: Mariacarla Moleti mmoleti@unime.it

Specialty section: This article was submitted to Cancer Endocrinology,

a section of the journal

Frontiers in Endocrinology

Received: 16 March 2017

Accepted: 08 May 2017

Published: 23 May 2017

Citation:

Moleti M, Sturniolo G, Di Mauro M,

Russo $M$ and Vermiglio $F$ (2017)

Female Reproductive Factors and

Differentiated Thyroid Cancer.

Front. Endocrinol. 8:111.

doi: 10.3389/fendo.2017.00111
Differentiated thyroid cancer (DTC) is markedly more common in women than men, the highest female-to-male ratio being recorded during the reproductive period. This evidence has led to the suggestion that female hormonal and reproductive factors may account for the observed DTC gender disparity. This review focuses on current evidence on the risk of DTC in conjunction with major female reproductive factors, including the impact of pregnancy on DTC occurrence and progression/recurrence. Overall, studies exploring the link between the risk of DTC and menstrual and menopausal factors, oral contraceptives and/or hormone replacement therapy, showed these associations, if any, to be generally weak. Nonetheless, there is some evidence that higher levels of exposure to estrogens during reproductive years may confer an increased risk of DTC. As far as pregnancy is concerned, it is unclear whether a potential association between parity and risk of DTC actually exists, and whether it is enhanced in the short-term following delivery. A possible role for pregnancy-related factors in DTC progression has been recently suggested by some reports, the results of which are consistent with a worse outcome in the short-term of women diagnosed with DTC during gestation compared to non-pregnant control patients. Also, some progression of disease has been described in women with structural evidence of disease prior to pregnancy. However, there seems to be no impact from pregnancy in DTC-related death or overall survival. Several in vitro and animal studies have evaluated the influence of estrogens $(E)$ and estrogen receptors (ERs) on thyroid cell proliferation. Presently available data are indicative of a role of $E$ and ERs in thyroid cancer growth, although considerable discrepancies in respect to ER expression patterns in thyroid cancer tissues actually exist. Further studies providing more direct evidence on the possible role of $E$ and of placental hormones and growth factors on thyroid growth may expand our knowledge on the mechanisms beyond the gender disparity of proliferative thyroid diseases.

\section{Keywords: thyroid cancer, pregnancy, reproductive factors, estrogens, estrogen receptors}

\section{INTRODUCTION}

Thyroid cancer is the most common endocrine malignancy and the eighth most common cancer in the USA (1). With few exceptions, over the last decades a trend toward an increasing incidence of thyroid cancer has been described in several geographic areas (2-7). This raise has been attributed to the increased incidence of small papillary thyroid cancer (PTC), although an increase in follicular thyroid cancer incidence rates (IRs) has also been recorded in both sexes (8). 
Overall, increased incidences of thyroid cancer in females are observed across different countries and ethnicities (3). Based on the National Cancer Institute's Surveillance, Epidemiology, and End Results cancer statistics, the age-adjusted IR of thyroid cancer in 2013 was $21.61 / 100,000$ women and 7.26/100,000 men, for a female-to-male $(\mathrm{F} / \mathrm{M})$ ratio of almost 3:1. However, because of differences between sexes in thyroid cancer peak age incidence, the $\mathrm{F} / \mathrm{M}$ ratio is higher during the reproductive period (4.1:1 at ages $20-49$ years), and steady decreases with advancing age (1.38:1 at ages $\geq 75$ years) (http://seer.cancer.gov/faststats, accessed on December 2016). In addition, reports analyzing gender distribution according to the histotypes collectively reveal a twofold to almost fourfold F/M IR ratios for differentiated thyroid cancer (DTC), but a lack of gender disparity for the medullary and the anaplastic types $(5,9-11)$.

Both the preponderance of DTC incidence in females and the incidence peak in women of childbearing age suggest that hormonal and reproductive factors may account for the observed DTC gender disparity. Here, we briefly review current evidence on the role of the major female reproductive factors associated with DTC risk and the impact of pregnancy on thyroid cancer occurrence, progression, or recurrence.

\section{METHODS}

The terms thyroid cancer/carcinoma or differentiated thyroid cancer/carcinoma were used in conjunction with the terms reproductive/menstrual/hormonal factors, reproduction, pregnancy to search MEDLINE for articles published in English in the last 20 years (1996-2016). Additional papers were searched by scrutinizing the reference lists of previously published reviews and meta-analyses.

\section{RESULTS}

\section{Menstrual Cycling}

Since the incidence of DTC in females abruptly increases at the time of puberty and declines after menopause (12), the relationship between menstrual factors and DTC risk has been addressed in a number of studies (13-31), the results of which are quite heterogeneous. Concerning age at menarche and DTC risk, most studies reported no significant associations, whereas other showed either early ( $<12$ years) $(16,20,29)$ or late $(>15-16$ years) $(13,16,18,27)$ age at menarche to be weakly associated with increased DTC risk. A history of irregular menstrual cycles has been reported to confer a higher risk of DTC, the magnitude of the observed associations being generally weak and/or limited to specific subsets of population $(18,27)$.

As far as menopause is concerned, most studies that examined the association of DTC with menopausal status, age at menopause, and type of menopause, failed to find consistent associations (14, 16-18, 21-25, 27, 28, 31). More recently, two meta-analyses showed postmenopausal status and older age at menopause to be, respectively, associated with a borderline significant reduction (RR 0.79, 95\% CI 0.62-1.01) (32) and increase (RR 1.24, 95\% CI 1.00-1.53) (33) of DTC risk. A further meta-analysis focusing on PTC only, also found late age at menopause to be associated with increased PTC risk $(\mathrm{RR}=1.39$, 95\% CI 1.03-1.89) (34).

A roughly twofold increased DTC risk was reported among women who underwent surgical menopause compared to premenopausal women $(13,14,19,31)$. In a pooled analysis of 14 case-control studies, Negri et al. found that the OR was 1.8 (95\% CI 1.4-2.4) for women with artificial menopause, compared to premenopausal women. The increased risk of DTC in women who underwent surgical menopause could be explained by an enhanced medical surveillance because of symptoms of sudden ovarian failure (35). Alternatively, since leiomyomas are the leading indication for hysterectomy globally and this condition is known to be associated with hyperestrogenism (36), the increased DTC risk associated with artificial menopause could result from the exposure to an underlying clinical conditionnamely, hyperestrogenism-possibly favoring the development of both uterine myomas and thyroid cancer $(30,35)$. A role for hyperestrogenism per se is also supported by the findings from a prospective study consisting of naturally postmenopausal women only in which a greater length of exposure to endogenous sex steroid hormones during reproductive years was associated with an increased risk of DTC. Indeed, thyroid cancer risk was found to be decreased with increasing age at menarche $[\geq 14$ vs $<12$ years: hazard ratio (HR) 0.62 , 95\% CI 0.36-1.05] but increased with both increasing age at natural menopause $(\geq 55$ vs $<50$ years: HR $2.24,95 \%$ CI 1.20-4.18) and greater lifetime number of ovulatory cycles ( $\geq 490$ vs $<415$ cycles: HR 2.40 , 95\% CI: $1.33-4.30$ ). Notably, in this study, a history of uterine leiomyomas was also associated with an increased risk of thyroid cancer (HR 1.72, 95\% CI: 1.18-2.50) (30).

In summary, studies exploring the risk of DTC in conjunction with menstrual and menopausal factors yielded rather equivocal results, as the associations, if any, are generally weak. Nonetheless, there is some evidence that higher levels of exposure to estrogens during reproductive years may confer an increased risk of thyroid cancer.

\section{Use of Exogenous Hormones}

Several large studies investigated the potential relation between oral contraceptive (OC) use and/or hormone replacement therapy (HRT) and DTC risk.

An analysis of pooled data based on 2,132 female thyroid cancer cases and 3,301 controls showed neither association between ever OC use and DTC risk nor relationship with duration or age at first use (37). However, the OR was higher for current OC users (OR 1.5, 95\% CI 1.0-2.1), declining 10 years after stopping (OR to $1.1,95 \%$ CI $0.8-1.4$ ). Consistent with the above analysis, the vast majority of studies published afterward also showed ever use of OCs or age at first/last use to be generally unrelated to DTC, with no significant trends with increasing duration of use $(14,17$, $18,21-23,25,27,28,30,38)$. In contrast, results from other studies suggest a reduced risk of DTC in OC users $(16,20,31)$, either irrespective of duration $(16,20)$ or related to prolonged OC use only $(26,31)$. Interestingly, a reduced risk of DTC (HR $0.63,95 \%$ CI $0.38-1.04$ ) with use of any contraceptive method and with intrauterine devices use was observed in one study (39). 
This finding raises the question of whether the reduced DTC risk in OC users may be related to the lack of physiological thyroid changes during gestation (40) because of the prevented pregnancies rather than to a protective role of OC per se.

With few exceptions $(26,27,31)$, studies providing information on HRT in relation to DTC overall indicate the use of estrogens in women of post-reproductive age not to modify cancer risk $(13,14,16-18,21,22,24,25,28,30,41,42)$. A recent prospective study (31) showed that, after stratifying for HRT type, no association could be found with progestin alone or progestin and estrogen combined, whereas estrogen use alone was significantly associated with increased risk of DTC (HR 1.67, 95\% CI 1.08-2.59).

The relationship between fertility-enhancing drugs and thyroid cancer risk has been less extensively investigated. In a pooled analysis, an overall OR of 1.6 (95\% CI 0.9-2.9) was calculated on the basis of 22/730 women affected with DTC and 29/1,167 controls who had used fertility drugs (37). In a series of 8,422 women evaluated for infertility, 18 of whom diagnosed with DTC, neither clomiphene nor gonadotropin use significantly increased the risk of thyroid cancer (43). In another study by the same group, the above association was investigated on a larger population ( 9,892 women) overall including 55 thyroid cancer cases, and with a follow-up extending to an average of 30 years. Once again, no association with clomiphene use was observed, although DTC risk was significantly enhanced among the heavily exposed patients $(\mathrm{HR}=1.96$, for those receiving $>2,250 \mathrm{mg}$ ) (44). By contrast, examining a cohort of 54,362 women with fertility problems, Hannibal found that women who had ever used clomiphene had a higher risk of thyroid cancer compared with those who had never used it (RRs 2.28, 95\% CI 1.08-4.82), with the risk being primarily increased among parous women (RR 3.76, 95\% CI 1.48-9.58) (44).

Overall, other fertility-enhancing drugs (follicle-stimulating hormone, human menopausal gonadotropin, gonadotropinreleasing hormone, or human chorionic gonadotropin) generally proved unrelated to DTC risk, with no association for all groups of fertility drugs relative to number of cycles or years since first use (43-47).

To summarize, current evidence does not support any strong relation between OC and/or HRT and DTC risk. Conversely, findings from some studies are suggestive of a potential association between clomiphene use and thyroid cancer. Mechanisms possibly responsible for the increased risk of DTC in clomipheneexposed women are not clear, although a role for hyperestrogenism arising from ovarian stimulation has been postulated (44). Under such circumstances, estrogens, either directly (12) or indirectly, through enhanced serum thyrotropin (TSH) levels (48) may enhance mitotic activity in the follicular cells of the thyroid gland and promote thyroid cancer development/progression (49). However, if that is the case, the reasons for a lack of association between DTC and other ovulation-stimulating agents, equally effective in inducing a state of hyperestrogenism, remain elusive.

Table 1 summarizes the main findings from original studies reporting significant associations between menstrual factors and use of exogenous hormones and DTC risk.

\section{Reproductive History}

After breast cancer, DTC represents the second most common malignancy diagnosed during pregnancy and the early postpartum period in the USA (50).

In a case-control study nested within a cohort of Swedish women, a weak association between parity and risk of thyroid cancer (OR for ever-parous women vs nulliparous 1.1, 95\% CI 1.0-1.3) was found. However, when the subset of PTC only was taken into account, there was a significantly increased risk for ever-parous vs nulliparous women (OR 1.3, 95\% CI 1.0-1.6), along with a positive linear trend with increasing number of live births. In addition, women during the first year after a live birth had an increased risk of DTC compared with women who delivered 10 or more years before (51). Similarly, a population-based case-control study carried out in the USA showed a transiently increased risk of PTC among women who had delivered a live birth within the 5 years before the reference date, and the risk was even more pronounced among women with two or more births (OR 4.2, 95\% CI 2.0-8.9) compared to women with one pregnancy only (OR 1.6, 95\% CI 1.0-2.7) (15). A short-term effect of pregnancy on thyroid cancer risk is also supported by pooled estimates of large datasets $(32,34,52,53)$ and findings from other studies $(16-18,27,31,54)$. However, other investigations concluded that ever being pregnant, number of births and/ or recency of pregnancies resulted in no increased $(23,26)$ or even decreased (22) risk of DTC (Table 2).

For all the above, it is unclear whether a potential association between parity and risk of DTC in women actually exists, and/ or whether it is limited to the short-term following delivery. Possible explanations include a closer clinical surveillance in women who had recent pregnancies on one hand, and an actual promoting role for placental growth factors and hormones on the other. Indeed, there is evidence that childbirth is an increased risk factor for goiter and thyroid nodule growth $(40,55,56)$, and a possible role for pregnancy-related factors in DTC progression has been postulated. In particular, compared to tumors developed in non-gravidic periods, DTC occurring during pregnancy or in the first-year postpartum was associated with a poorer prognosis (OR 15.88, 95\% CI 4.01-62.77, $p=0.001$ ) (57). Similarly, a retrospective analysis of 340 women affected with DTC and aged $\leq 45$ years showed a significantly higher rate of persistent/ recurrent disease among those diagnosed during pregnancy or within 2 years after delivery as compared to both nulliparous and women with DTC diagnosis > 2 years after delivery (58).

Another issue concerns the potential adverse impact of pregnancy on the risk of disease progression in women diagnosed with DTC months to years prior to pregnancy. Studies comparing structural imaging and/or serum Tg levels before pregnancy and shortly after delivery in women previously treated for DTC overall indicate that pregnancy has no unfavorable impact in women free of disease prior to pregnancy (59-62) or in those with indeterminate or biochemical incomplete response (62). By contrast, some progression has been described in patients with structural evidence of disease prior to pregnancy (60-62). Yet, evidence is still insufficient to conclude that in this subset of women disease progression was related to pregnancy per se or it would have likewise occurred regardless of pregnancy. 
TABLE 1 | Summary results of original studies reporting significant associations between menstrual factors, exogenous hormones, and thyroid cancer.

\begin{tabular}{|c|c|c|c|c|c|}
\hline Reference & Country & Study design & Study population $(n)$ & $\begin{array}{l}\text { Study } \\
\text { population } \\
\text { age (years) }\end{array}$ & DTC risk \\
\hline Galanti et al. (13) & Norway, Sweden & Case-control & 191 cases vs 341 controls & $18-75$ & $\begin{array}{l}\uparrow \text { For onset of menarche }>15 \text { years } \\
\text { and for menopause }>48 \text { years of age }\end{array}$ \\
\hline Mack et al. (14) & California (USA) & Case-control & 292 cases vs 292 controls & $15-54$ & $\begin{array}{l}\uparrow \text { In women who had never menstruated regularly } \\
\text { and in those who underwent bilateral oophorectomy }\end{array}$ \\
\hline Rossing et al. (15) & $\begin{array}{l}\text { Washington State } \\
\text { (USA) }\end{array}$ & Case-control & 410 cases vs 574 controls & $18-64$ & $\begin{array}{l}\uparrow \text { In women } \geq 45 \text { years with surgical menopause } \\
\text { (regardless of oophorectomy) }\end{array}$ \\
\hline \multirow[t]{2}{*}{$\begin{array}{l}\text { Sakoda and } \\
\text { Horn-Ross (16) }\end{array}$} & \multirow[t]{2}{*}{ California (USA) } & \multirow[t]{2}{*}{ Case-control } & \multirow[t]{2}{*}{544 cases vs 558 controls } & \multirow[t]{2}{*}{$20-74$} & $\begin{array}{l}\uparrow \text { For onset of menarche }<12 \text { or }>14 \text { years, with significant } \\
\text { differences among age- and ethnic-specific subgroups }\end{array}$ \\
\hline & & & & & $\downarrow$ In ever OC users (irrespective of duration) \\
\hline Truong et al. (18) & New Caledonia & Case-control & 293 cases vs 354 controls & $>18$ & $\begin{array}{l}\uparrow \text { For onset of menarche }>15 \text { years and in women } \\
\text { who had never menstruated regularly, with significant } \\
\text { differences among ethnic-specific subgroups }\end{array}$ \\
\hline Brindel et al. (19) & French Polynesia & Case-control & 201 cases vs 324 controls & $<56$ & $\uparrow$ In women with natural or surgical menopause \\
\hline \multirow[t]{2}{*}{ Xhaard et al. (20) } & \multirow[t]{2}{*}{ France } & \multirow[t]{2}{*}{ Case-control } & \multirow[t]{2}{*}{633 cases vs 677 controls } & \multirow[t]{2}{*}{$<35$} & $\uparrow$ For onset of menarche $<12$ years \\
\hline & & & & & $\downarrow$ In ever OC users (irrespective of duration) \\
\hline Schonfeld et al. (26) & USA & Cohort & $\begin{array}{l}312 \text { cases from a cohort of } \\
187,865 \text { women }\end{array}$ & $50-71$ & $\downarrow$ In OC users (prolonged use only) \\
\hline Horn-Ross et al. (27) & California (USA) & Cohort & $\begin{array}{l}233 \text { cases from a cohort of } \\
117,646 \text { women }\end{array}$ & $<80$ & $\begin{array}{l}\uparrow \text { (in women age }<45 \text { years at baseline) for } \\
\text { onset of menarche } \geq 14 \text { years, longer ( }>30 \text { days) } \\
\text { adolescent menstrual cycles }\end{array}$ \\
\hline Sungwalee et al. (29) & Thailand & Cohort & $\begin{array}{l}17 \text { cases from a cohort of } \\
10,767 \text { women }\end{array}$ & $30-69$ & $\uparrow$ For onset of menarche $<14$ \\
\hline Braganza et al. (30) & USA & Cohort & $\begin{array}{l}127 \text { cases from a cohort of } \\
70,047 \text { women }\end{array}$ & $50-78$ & $\begin{array}{l}\uparrow \text { For older age ( } \geq 55 \text { years) at natural menopause and } \\
\text { greater estimated lifetime number of ovulatory cycles }\end{array}$ \\
\hline \multirow[t]{2}{*}{ Zamora-Ros et al. (31) } & \multirow[t]{2}{*}{ Europe } & \multirow[t]{2}{*}{ Cohort } & \multirow{2}{*}{$\begin{array}{l}537 \text { cases from a cohort of } \\
345,157 \text { women }\end{array}$} & \multirow{2}{*}{$\begin{array}{c}\text { Mean } \\
\text { age } 51\end{array}$} & $\uparrow$ In women with surgical menopause \\
\hline & & & & & $\downarrow$ In OC users (prolonged use only) \\
\hline Hannibal et al. (44) & Denmark & Cohort & $\begin{array}{l}29 \text { cases from a cohort of } \\
54,362 \text { women }\end{array}$ & $18-55$ & †in clomiphene-treated women \\
\hline $\begin{array}{l}\text { Calderon-Margalit } \\
\text { et al. (45) }\end{array}$ & Israel & Cohort & $\begin{array}{l}71 \text { cases from a cohort of } \\
15,030 \text { women }\end{array}$ & $\begin{array}{c}\text { Mean } \\
\text { age } \sim 28\end{array}$ & $\uparrow$ In clomiphene-treated women \\
\hline
\end{tabular}

DTC, differentiated thyroid cancer; OC, oral contraceptive; $\uparrow$, increased risk; $\downarrow$, decreased risk.

Finally, two subsequent studies involving Japanese women affected with micro-PTC and selected for active surveillance without therapeutic intervention (63) came to opposite conclusions. In the first study (64), significant changes $(\geq 3 \mathrm{~mm})$ in the size of micro-PTCs were observed more frequently in women who had experienced at least one pregnancy during the followup period compared with an age-adjusted control group of non-pregnant female patients (44.4 vs $11.1 \%$ ). However, a larger retrospective analysis including all patients who experienced pregnancy and delivery during the Hospital's active surveillance program demonstrated the incidence of growth of micro-PTCs during pregnancy to be low at $8 \%$, with no cases of lymph node metastases developing during pregnancy (65).

Thus, based on the few available retrospective studies the rates of disease recurrence/persistence are seemingly somewhat higher among women with DTC occurring during pregnancy than in non-pregnant control patients. Importantly, as far as long-term outcome is concerned, there seem to be no impact from pregnancy in DTC-related death or overall survival
(66-69) Also, presently available data indicate that pregnancy does not impact thyroid cancer prognosis in patients with no evidence of persistent disease prior to pregnancy. Conversely, whether pregnancy actually poses any risks for progression in women with preexisting structural disease, and whether this event is related to or independent of pregnancy, needs to be further investigated.

\section{Estrogen and Estrogen Receptors (ERs) in Benign and Malignant Thyroid Diseases}

The evidence of a three to four times higher prevalence of proliferative thyroid diseases in females than in males and their peak incidence in premenopausal women strongly suggests that female sex hormones may play a role in the pathogenesis of both benign and malignant thyroid tumors. Several in vitro and animal studies have evaluated the influence of sex steroids on proliferation of thyroid cells, with estrogens (E) and ERs being the most investigated target of current research. 
TABLE 2 | Summary results of original studies reporting significant associations between pregnancy and thyroid cancer risk/prognosis.

\begin{tabular}{|c|c|c|c|c|c|}
\hline Reference & Country & Study design & Study population (n) & $\begin{array}{l}\text { Study } \\
\text { population } \\
\text { age (years) }\end{array}$ & DTC risk/prognosis \\
\hline Rossing et al. (15) & $\begin{array}{l}\text { Washington } \\
\text { State (USA) }\end{array}$ & Case-control & 410 cases vs 574 controls & $18-64$ & $\begin{array}{l}\uparrow \text { In women }<45 \text { years who had delivered one or more } \\
\text { live births within the } 5 \text { years before DTC diagnosis }\end{array}$ \\
\hline $\begin{array}{l}\text { Sakoda and } \\
\text { Horn-Ross (16) }\end{array}$ & California (USA) & Case-control & 544 cases vs 558 controls & $20-74$ & $\begin{array}{l}\uparrow \text { In uni/multiparous women who had delivered one or } \\
\text { more live births within the } 5 \text { years before DTC diagnosis }\end{array}$ \\
\hline Truong et al. (18) & New Caledonia & Case-control & 293 cases vs 354 controls & 218 & $\begin{array}{l}\uparrow \text { In women }<45 \text { years with a trend toward an increase } \\
\text { in risk with the number of full-term pregnancies }\end{array}$ \\
\hline Navarro Silvera et al. (22) & Canada & Cohort & $\begin{array}{l}169 \text { cases from a cohort } \\
\text { of } 89,797 \text { women }\end{array}$ & $40-59$ & $\begin{array}{l}\downarrow \text { Among women with } 5 \text { or more live births vs } \\
\text { nulliparous }\end{array}$ \\
\hline Horn-Ross et al. (27) & California (USA) & Cohort & $\begin{array}{l}233 \text { cases from a cohort } \\
\text { of } 117,646 \text { women }\end{array}$ & $<80$ & $\begin{array}{l}\uparrow \text { In younger women who had delivered within the } \\
5 \text { years before DTC diagnosis }\end{array}$ \\
\hline Zamora-Ros et al. (31) & Europe & Cohort & $\begin{array}{l}537 \text { cases from a cohort } \\
\text { of } 345,157 \text { women }\end{array}$ & $\begin{array}{c}\text { Mean } \\
\text { age } 51\end{array}$ & $\begin{array}{l}\uparrow \text { In women who had delivered within the } 5 \text { years } \\
\text { before DTC diagnosis }\end{array}$ \\
\hline Galanti et al. (51) & Sweden & Case-control & $\begin{array}{l}1,409 \text { cases vs } 7,019 \\
\text { controls }\end{array}$ & $15-59$ & $\begin{array}{l}\uparrow \text { In uni/multiparous women, especially during the } \\
\text { first year after a live birth vs women who delivered } \\
10 \text { or more years before }\end{array}$ \\
\hline Vannucchi et al. (57) & Italy & Retrospective & $\begin{array}{l}\text { DTC diagnosis: } \\
\begin{array}{l}n=47 \geq 1 \text { year after delivery } \\
n=14 \text { during pregnancy or } \\
<1 \text { year after delivery } \\
n=61 \text { before pregnancy or } \\
\text { nulliparous }\end{array}\end{array}$ & $<45$ & $\begin{array}{l}\text { Poorer prognosis for DTC diagnosed during pregnancy } \\
\text { or in the first year after delivery compared to tumors } \\
\text { developed in non-gravidic periods }\end{array}$ \\
\hline Messuti et al. (58) & Italy & Retrospective & $\begin{array}{l}\text { DTC diagnosis: } \\
\begin{array}{l}n=152 \geq 2 \text { years after } \\
\text { delivery } \\
n=38 \text { during pregnancy or } \\
<2 \text { years after delivery } \\
n=150 \text { nulliparous }\end{array}\end{array}$ & $<45$ & $\begin{array}{l}\text { Higher risk of persistence/recurrence of disease } \\
\text { for DTC diagnosed during pregnancy or within the } \\
\text { second year after delivery than in control groups }\end{array}$ \\
\hline
\end{tabular}

DTC, differentiated thyroid cancer; $\uparrow$, increased risk; $\downarrow$, decreased risk.

Either endogenous or exogenous hyperestrogenism are known to indirectly affect thyroid function, through an increase of serum thyroxine binding globulin (TBG) concentrations, due to both a stimulation of liver TBG synthesis and a reduced plasma clearance of the protein (43). This event is particularly marked during pregnancy and is accompanied by a trend toward a reduction in free-thyroid hormone concentrations and a subsequent stimulation of the pituitary-thyroid axis. In condition of iodine sufficiency, the enhanced thyroidal stimulation during pregnancy has no or little impact on thyroid function and growth. In contrast, a less than adequate iodine supply throughout gestation results in sustained hyperstimulation of the maternal thyroid gland, which may be responsible for goiter occurrence and/or thyroid nodules enlargement (70). Notably, gestational goiter may only partially regress after parturition (71), which may partly explain the preponderance of goiter in the female population. In addition, several lines of evidence demonstrate that $17-\beta$-estradiol (E2) stimulation induces cell growth in primary cultures of human thyrocytes from benign and malignant thyroid nodules, FRTL-5 rat thyroid cell line, and in most human thyroid carcinoma cell lines (72-76). Also, in vitro E2 exposure enhances metastatic properties of both normal and thyroid cancer cell lines by targeting the expression of molecules involved in cell adhesion, migration, and invasiveness, such as $\beta$-catenin, E-cadherin, vimentin, and matrix metalloproteinases (77-80). The growth-promoting effect of E2 on thyroid cells is mediated by a classical genomic pathway involving nuclear ERs and by rapid non-genomic signaling events via a membrane-associated estrogen receptor $(12,81)$. The latter involves both the mitogen-activated protein kinase and the phosphatidylinositol 3-kinase signaling pathways, which are known to play a key role in thyroid tumorigenesis.

The expression of ERs has been investigated by immunohistochemistry, binding assays, and RT-PCR in a number of studies, the results of which are quite heterogeneous, irrespective of the technique employed $(10,12,82)$. Nevertheless, both ER $\alpha$ and ER $\beta$ have been detected in variable proportions in normal thyroid tissue, as well as in benign and malignant thyroid lesions and in most thyroid cancer cell lines (82). The expression of ER isoforms would be differentially regulated by E2, since E2 treatment of human thyroid papillary carcinoma cells (KAT5) was found to significantly increase the expression of $E R \alpha$ but did not affect that of $\operatorname{ER} \beta$ (76). Present evidence indicates that ER $\alpha$ and $\operatorname{ER} \beta$ exert opposite functions on thyroid cancer cell, with ER $\alpha$ being responsible for cell proliferation and ER $\beta$ having pro-apoptotic functions (81). Mechanisms beyond these effects involve changes in the balance between the antiapoptotic B-cell lymphoma 2 
(Bcl-2) protein and the pro-apoptotic Bax protein, which are upregulated by $\mathrm{ER} \alpha$ and $\mathrm{ER} \beta$, respectively (76). Interestingly, an increase in $\operatorname{ER} \alpha$ but a decrease in $\operatorname{ER} \beta$ expression has been observed in human thyroid cancer cells $(83,84)$, which suggests that, as for breast cancer, an imbalance in the expression of the two isoforms may favor human thyroid cancer progression $(76,81)$. Consistent with this hypothesis are the findings from some recent clinical studies, overall arguing for an association between $\mathrm{ER} \alpha$ expression and/or partial or total lack of ER $\beta$ expression in DTCs and a more aggressive presentation or a trend toward the presence of local metastases at diagnosis (85-87). Relative to the expression of ERs in DTC diagnosed during pregnancy, one study found the vast majority (87.5\%) of tumors diagnosed during or soon after pregnancy to test positively for ER $\alpha$, which, according to the authors, could explain the worse outcome observed in this subset of patients compared to non-pregnant women (57). Another study, however, while confirming a significant correlation between pregnancy and a poorer outcome of DTC, found the immunohistochemical expression of $\mathrm{ER} \alpha$ and $\mathrm{ER} \beta$ to be globally low and unrelated to the time of tumor diagnosis in respect of pregnancy (58).

A role for E2 in thyroid cancer occurrence is also suggested by the higher than expected rates of thyroid cancer in women with a history of breast cancer and vice versa. Indeed, a recent metaanalysis focusing on this issue showed the ORs of developing thyroid or breast cancer as secondary malignancy after diagnosis with the other to be increased at 1.55 (95\% CI 1.44-1.67) and 1.32 (95\% CI 1.23-1.42), respectively (88).

Mechanisms underlying the bidirectional association between thyroid and breast cancer are still unclear and may involve, either separately or in combination, both exogenous (i.e., increase in surveillance, radiation exposure, environmental risk factors) and endogenous factors (88). The latter ones include genetic susceptibility, as is the case for Cowden and Cowdenlike syndromes (89), as well as a common molecular mechanism mediated by sex steroid receptors. In this regard, compared to control groups of breast cancer as the only malignancy, the expression of both ER and progesterone receptor (PR) was found to be significantly increased in breast cancer specimens

\section{REFERENCES}

1. SEER. Cancer Statistics Factsheets: Thyroid Cancer. Bethesda, MD: National Cancer Institute. Available from: http://seer.cancer.gov/statfacts/html/thyro.html (accessed December 2016).

2. Simard EP, Ward EM, Siegel R, Jemal A. Cancers with increasing incidence trends in the United States: 1999 through 2008. CA Cancer J Clin (2012) 62:118-28. doi:10.3322/caac.20141

3. Ferlay J, Soerjomataram I, Ervik M, Dikshit R, Eser S, Mathers C, et al. GLOBOCAN 2012 v1.0, Cancer Incidence and Mortality Worldwide: IARC Cancer Base No. 11. Lyon: International Agency for Research on Cancer (2013).

4. Kilfoy BA, Zheng T, Holford TR, Han X, Ward MH, Sjodin A, et al. International patterns and trends in thyroid cancer incidence, 1973-2002. Cancer Causes Control (2009) 20:525-31. doi:10.1007/s10552-008-9260-4

5. Aschebrook-Kilfoy B, Ward MH, Sabra MM, Devesa SS. Thyroid cancer incidence patterns in the United States by histologic type, 1992-2006. Thyroid (2011) 21:125-34. doi:10.1089/thy.2010.0021 from women who also had DTC, regardless of which of the two cancers had occurred first and/or of the latency to detection of the second malignancy $(90,91)$. Interestingly, evidence has been provided showing that rearranged during transfection/ papillary thyroid carcinoma (RET/PTC) oncogene is induced by estrogen in breast cancer cells, and the RET/PTC kinase signaling enhances estrogen-driven cell proliferation $(92,93)$. Since RET/PTC rearrangements are found in approximately $20 \%$ of spontaneous PTCs (94), a shared mechanism mediated by ER/ $\mathrm{PR}$ signaling and involving the RET/PTC-dependent tyrosine kinase pathways might underlie the observed association of breast cancer and thyroid cancer.

\section{CONCLUDING REMARKS}

Presently available clinical and experimental data are indicative of a role of estrogens and their receptors in thyroid cancer growth. Nonetheless, considerable discrepancies between studies in respect to ER expression patterns in thyroid cancer tissues actually exist. Also, it is still unclear whether the pregnancy-related hyperestrogenic state may account for the poorer outcome observed in women diagnosed with DTC during gestation. In this regard, it should be considered that a number of placental hormones (other than estrogens) and growth factors (i.e., insulin-like growth factors 1 and 2, epidermal growth factor, vascular endothelial growth factor, and members of the transforming growth factor- $\beta$ superfamily) are increased within the maternal circulation throughout gestation (95) and might theoretically contribute to thyroid cancer occurrence/progression in pregnancy. Further studies providing more direct evidence for a role of $\mathrm{E} 2$ in thyroid carcinogenesis, and investigations on the effects, if any, of placental growth factors on thyroid growth, may be helpful in understanding the mechanisms beyond the gender disparity of proliferative thyroid diseases.

\section{AUTHOR CONTRIBUTIONS}

All the authors listed have made substantial, direct, and intellectual contribution to the work and approved it for publication.

6. Pellegriti G, Frasca F, Regalbuto C, Squatrito S, Vigneri R. Worldwide increasing incidence of thyroid cancer: update on epidemiology and risk factors. J Cancer Epidemiol (2013) 2013:965212. doi:10.1155/2013/965212

7. Aschebrook-Kilfoy B, Kaplan EL, Chiu BC, Angelos P, Grogan RH. The acceleration in papillary thyroid cancer incidence rates is similar among racial and ethnic groups in the United States. Ann Surg Oncol (2013) 20:2746-53. doi:10.1245/s10434-013-2892-y

8. Aschebrook-Kilfoy B, Grogan RH, Ward MH, Kaplan E, Devesa SS. Follicular thyroid cancer incidence patterns in the United States, 1980-2009. Thyroid (2013) 23:1015-21. doi:10.1089/thy.2012.0356

9. Grubbs EG, Rich TA, Li G, Sturgis EM, Younes MN, Myers JN, et al. Recent advances in thyroid cancer. Curr Probl Surg (2008) 45:156-250. doi:10.1067/j. cpsurg.2007.12.010

10. Yao R, Chiu CG, Strugnell SS, Gill S, Wiseman SM. Gender differences in thyroid cancer: a critical review. Expert Rev Endocrinol Metab (2011) 6:215-43. doi:10.1586/eem.11.9

11. Rahbari R, Zhang L, Kebebew E. Thyroid cancer gender disparity. Future Oncol (2010) 6:1771-9. doi:10.2217/fon.10.127 
12. Derwahl M, Nicula D. Estrogen and its role in thyroid cancer. Endocr Relat Cancer (2014) 21:T273-83. doi:10.1530/ERC-14-0053

13. Galanti MR, Hansson L, Lund E, Bergström R, Grimelius L, Stalsberg H, et al. Reproductive history and cigarette smoking as risk factors for thyroid cancer in women: a population-based case-control study. Cancer Epidemiol Biomarkers Prev (1996) 5:425-31.

14. Mack WJ, Preston-Martin S, Bernstein L, Qian D, Xiang M. Reproductive and hormonal risk factors for thyroid cancer in Los Angeles county females. Cancer Epidemiol Biomarkers Prev (1999) 8:991-7.

15. Rossing MA, Voigt LF, Wicklund KG, Daling JR. Reproductive factors and risk of papillary thyroid cancer in women. Am J Epidemiol (2000) 151:765-72. doi:10.1093/oxfordjournals.aje.a010276

16. Sakoda LC, Horn-Ross PL. Reproductive and menstrual history and papillary thyroid cancer risk: the San Francisco bay area thyroid cancer study. Cancer Epidemiol Biomarkers Prev (2002) 11:51-7.

17. Memon A, Darif M, Al-Saleh K, Suresh A. Epidemiology of reproductive and hormonal factors in thyroid cancer: evidence from a case-control study in the Middle East. Int J Cancer (2002) 97:82-9. doi:10.1002/ijc.1573

18. Truong T, Orsi L, Dubourdieu D, Rougier Y, Hémon D, Guénel P. Role of goiter and of menstrual and reproductive factors in thyroid cancer: a populationbased case-control study in New Caledonia (South Pacific), a very high incidence area. Am J Epidemiol (2005) 161:1056-65. doi:10.1093/aje/kwi136

19. Brindel P, Doyon F, Rachédi F, Boissin JL, Sebbag J, Shan L, et al. Menstrual and reproductive factors in the risk of differentiated thyroid carcinoma in native women in French Polynesia: a population-based case-control study. Am J Epidemiol (2008) 167:219-29. doi:10.1093/aje/kwm288

20. Xhaard C, Rubino C, Cléro E, Maillard S, Ren Y, Borson-Chazot F, et al. Menstrual and reproductive factors in the risk of differentiated thyroid carcinoma in young women in France: a population-based case-control study. Am J Epidemiol (2014) 180:1007-17. doi:10.1093/aje/kwu220

21. Iribarren C, Haselkorn T, Tekawa IS, Friedman GD. Cohort study of thyroid cancer in a San Francisco bay area population. Int J Cancer (2001) 93:745-50. doi:10.1002/ijc.1377

22. Navarro Silvera SA, Miller AB, Rohan TE. Risk factors for thyroid cancer: a prospective cohort study. Int J Cancer (2005) 116:433-8. doi:10.1002/ijc. 21079

23. Wong EY, Ray R, Gao DL, Wernli KJ, Li W, Fitzgibbons ED, et al. Reproductive history, occupational exposures, and thyroid cancer risk among women textile workers in Shanghai, China. Int Arch Occup Environ Health (2006) 79:251-8. doi:10.1007/s00420-005-0036-9

24. Pham TM, Fujino Y, Mikami H, Okamoto N, Hoshiyama Y, Tamakoshi A, et al. Reproductive and menstrual factors and thyroid cancer among Japanese women: the Japan collaborative cohort study. J Womens Health (Larchmt) (2009) 18:331-5. doi:10.1089/jwh.2008.1038

25. Meinhold CL, Ron E, Schonfeld SJ, Alexander BH, Freedman DM, Linet MS, et al. Nonradiation risk factors for thyroid cancer in the US radiologic technologists study. Am J Epidemiol (2010) 171:242-52. doi:10.1093/aje/kwp354

26. Schonfeld SJ, Ron E, Kitahara CM, Brenner A, Park Y, Sigurdson AJ, et al. Hormonal and reproductive factors and risk of postmenopausal thyroid cancer in the NIH-AARP diet and health study. Cancer Epidemiol (2011) 35:e85-90. doi:10.1016/j.canep.2011.05.009

27. Horn-Ross PL, Canchola AJ, Ma H, Reynolds P, Bernstein L. Hormonal factors and the risk of papillary thyroid cancer in the California teachers study cohort. Cancer Epidemiol Biomarkers Prev (2011) 20:1751-9. doi:10.1158/1055-9965. EPI-11-0381

28. Kabat GC, Kim MY, Wactawski-Wende J, Lane D, Wassertheil-Smoller S, Rohan TE. Menstrual and reproductive factors, exogenous hormone use, and risk of thyroid carcinoma in postmenopausal women. Cancer Causes Control (2012) 23:2031-40. doi:10.1007/s10552-012-0084-x

29. Sungwalee W, Vatanasapt P, Kamsa-Ard S, Suwanrungruang K, Promthet S. Reproductive risk factors for thyroid cancer: a prospective cohort study in Khon Kaen, Thailand. Asian Pac J Cancer Prev (2013) 14:5153-5. doi:10.7314/ APJCP.2013.14.9.5153

30. Braganza MZ, de González AB, Schonfeld SJ, Wentzensen N, Brenner AV, Kitahara CM. Benign breast and gynecologic conditions, reproductive and hormonal factors, and risk of thyroid cancer. Cancer Prev Res (Phila) (2014) 7:418-25. doi:10.1158/1940-6207.CAPR-13-0367

31. Zamora-Ros R, Rinaldi S, Biessy C, Tjønneland A, Halkjaer J, Fournier A, et al. Reproductive and menstrual factors and risk of differentiated thyroid carcinoma: the EPIC study. Int J Cancer (2015) 136:1218-27. doi:10.1002/ ijc. 29067

32. Caini S, Gibelli B, Palli D, Saieva C, Ruscica M, Gandini S. Menstrual and reproductive history and use of exogenous sex hormones and risk of thyroid cancer among women: a meta-analysis of prospective studies. Cancer Causes Control (2015) 26:511-8. doi:10.1007/s10552-015-0546-Z

33. Cao Y, Wang Z, Gu J, Hu F, Qi Y, Yin Q, et al. Reproductive factors but not hormonal factors associated with thyroid cancer risk: a systematic review and meta-analysis. Biomed Res Int (2015) 2015:103515. doi:10.1155/2015/103515

34. Wang P, Lu L, Qi F, Qiu F. Increased risk of papillary thyroid cancer related to hormonal factors in women. Tumour Biol (2015) 36:5127-32. doi:10.1007/ s13277-015-3165-0

35. Negri E, Dal Maso L, Ron E, La Vecchia C, Mark SD, Preston-Martin S, et al. A pooled analysis of case-control studies of thyroid cancer. II. Menstrual and reproductive factors. Cancer Causes Control (1999) 10:143-55. doi:10.1023/ A:1008880429862

36. Parker WH. Etiology, symptomatology, and diagnosis of uterine myomas. Fertil Steril (2007) 87:725-36. doi:10.1016/j.fertnstert.2007.01.093

37. La Vecchia C, Ron E, Franceschi S, Dal Maso L, Mark SD, Chatenoud L, et al. A pooled analysis of case-control studies of thyroid cancer. III. Oral contraceptives, menopausal replacement therapy and other female hormones. Cancer Causes Control (1999) 10:157-66. doi:10.1023/A:1008832513932

38. Rosenblatt KA, Gao DL, Ray RM, Nelson ZC, Wernli KJ, Li W, et al. Oral contraceptives and the risk of all cancers combined and site-specific cancers in Shanghai. Cancer Causes Control (2009) 20:27-34. doi:10.1007/ s10552-008-9213-y

39. Dorjgochoo T, Shu XO, Li HL, Qian HZ, Yang G, Cai H, et al. Use of oral contraceptives, intrauterine devices and tubal sterilization and cancer risk in a large prospective study from 1996 to 2006. Int J Cancer (2009) 124:2442-9. doi:10.1002/ijc.24232

40. Moleti M, Trimarchi F, Vermiglio F. Thyroid physiology in pregnancy. Endocr Pract (2014) 20:589-96. doi:10.4158/EP13341.RA

41. Zivaljevic V, Vlajinac H, Jankovic R, Marinkovic J, Dzodic R, Sipeti Grujii S, et al. Case-control study of female thyroid cancer-menstrual, reproductive and hormonal factors. Eur J Cancer Prev (2003) 12:63-6. doi:10.1097/ 00008469-200302000-00010

42. Fernandez E, Gallus S, Bosetti C, Franceschi S, Negri E, La Vecchia C Hormone replacement therapy and cancer risk: a systematic analysis from a network of case-control studies. Int J Cancer (2003) 105:408-12. doi:10.1002/ ijc. 11083

43. Althuis MD, Scoccia B, Lamb EJ, Moghissi KS, Westhoff CL, Mabie JE, et al. Melanoma, thyroid, cervical, and colon cancer risk after use of fertility drugs. Am J Obstet Gynecol (2005) 193:668-74. doi:10.1016/j. ajog.2005.01.091

44. Hannibal CG, Jensen A, Sharif H, Kjaer SK. Risk of thyroid cancer after exposure to fertility drugs: results from a large Danish cohort study. Hum Reprod (2008) 23:451-6. doi:10.1093/humrep/dem381

45. Calderon-Margalit R, Friedlander Y, Yanetz R, Kleinhaus K, Perrin MC, Manor O, et al. Cancer risk after exposure to treatments for ovulation induction. Am J Epidemiol (2009) 169:365-75. doi:10.1093/aje/kwn318

46. Silva IS, Wark PA, McCormack VA, Mayer D, Overton C, Little V, et al. Ovulation-stimulation drugs and cancer risks: a long-term follow-up of a British cohort. Br J Cancer (2009) 100:1824-31. doi:10.1038/ sj.bjc. 6605086

47. Yli-Kuha AN, Gissler M, Klemetti R, Luoto R, Hemminki E. Cancer morbidity in a cohort of 9175 Finnish women treated for infertility. Hum Reprod (2012) 27:1149-55. doi:10.1093/humrep/des031

48. Krassas GE, Poppe K, Glinoer D. Thyroid function and human reproductive health. Endocr Rev (2010) 31:702-55. doi:10.1210/er.2009-0041

49. McLeod DS. Thyrotropin in the development and management of differentiated thyroid cancer. Endocrinol Metab Clin North Am (2014) 43:367-83. doi:10.1016/j.ecl.2014.02.012

50. Smith LH, Danielsen B, Allen ME, Cress R. Cancer associated with obstetric delivery: results of linkage with the California cancer registry. Am J Obstet Gynecol (2003) 189:1128-35. doi:10.1067/S0002-9378(03)00537-4

51. Galanti MR, Lambe M, Ekbom A, Sparen P, Pettersson B. Parity and risk of thyroid cancer: a nested case-control study of a nationwide Swedish cohort. Cancer Causes Control (1995) 6:37-44. doi:10.1007/BF00051679 
52. Zhou YQ, Zhou Z, Qian MF, Gong T, Wang JD. Association of thyroid carcinoma with pregnancy: a meta-analysis. Mol Clin Oncol (2015) 3:341-6. doi:10.3892/mco.2014.472

53. Zhu J, Zhu X, Tu C, Li Y, Qian K, Jiang C, et al. Parity and thyroid cancer risk: a meta-analysis of epidemiological studies. Cancer Med (2016) 5:739-52. doi:10.1002/cam4.604

54. Peterson E, De P, Nuttall R. BMI, diet and female reproductive factors as risks for thyroid cancer: a systematic review. PLoS One (2012) 7:e29177. doi:10.1371/journal.pone.0029177

55. Kung AW, Chau MT, Lao TT, Tam SC, Low LC. The effect of pregnancy on thyroid nodule formation. J Clin Endocrinol Metab (2002) 87:1010-4. doi:10.1210/jcem.87.3.8285

56. Neale D, Burrow G. Thyroid disease in pregnancy. Obstet Gynecol Clin North Am (2004) 31:893-905. doi:10.1016/j.ogc.2004.09.001

57. Vannucchi G, Perrino M, Rossi S, Colombo C, Vicentini L, Dazzi D, et al. Clinical and molecular features of differentiated thyroid cancer diagnosed during pregnancy. Eur J Endocrinol (2010) 162:145-51. doi:10.1530/EJE-09-0761

58. Messuti I, Corvisieri S, Bardesono F, Rapa I, Giorcelli J, Pellerito R, et al. Impact of pregnancy on prognosis of differentiated thyroid cancer: clinical and molecular features. Eur J Endocrinol (2014) 170:659-66. doi:10.1530/ EJE-13-0903

59. Rosário PW, Barroso AL, Purisch S. The effect of subsequent pregnancy on patients with thyroid carcinoma apparently free of the disease. Thyroid (2007) 17:1175-6. doi:10.1089/thy.2007.0242

60. Leboeuf R, Emerick LE, Martorella AJ, Tuttle RM. Impact of pregnancy on serum thyroglobulin and detection of recurrent disease shortly after delivery in thyroid cancer survivors. Thyroid (2007) 17:543-7. doi:10.1089/thy.2007. 0020

61. Hirsch D, Levy S, Tsvetov G, Weinstein R, Lifshitz A, Singer J, et al. Impact of pregnancy on outcome and prognosis of survivors of papillary thyroid cancer. Thyroid (2010) 20:1179-85. doi:10.1089/thy.2010.0081

62. Rakhlin L, Fish S, Tuttle RM. Response to therapy status is an excellent predictor of pregnancy-associated structural disease progression in patients previously treated for differentiated thyroid cancer. Thyroid (2017) 27:396-401. doi:10.1089/thy.2016.0501

63. Ito $Y$, Miyauchi A, Inoue H, Fukushima M, Kihara M, Higashiyma T, et al. An observation trial for papillary thyroid microcarcinoma in Japanese patients. World J Surg (2010) 34:28-35. doi:10.1007/s00268-009-0303-0

64. Shindo H, Amino N, Ito Y, Kihara M, Kobayashi K, Miya A, et al. Papillary thyroid microcarcinoma might progress during pregnancy. Thyroid (2014) 24:840-4. doi:10.1089/thy.2013.0527

65. Ito $\mathrm{Y}$, Miyauchi A, Kudo $\mathrm{T}$, Ota $\mathrm{H}$, Yoshioka $\mathrm{K}$, Oda $\mathrm{H}$, et al. Effects of pregnancy on papillary microcarcinomas of the thyroid re-evaluated in the entire patient series at Kuma hospital. Thyroid (2016) 26:156-60. doi:10.1089/ thy. 2015.0393

66. Herzon FS, Morris DM, Segal MN, Rauch G, Parnell T. Coexistent thyroid cancer and pregnancy. Arch Otolaryngol Head Neck Surg (1994) 120:1191-3. doi:10.1001/archotol.1994.01880350009002

67. Moosa M, Mazzaferri EL. Outcome of differentiated thyroid cancer diagnosed in pregnant women. J Clin Endocrinol Metab (1997) 82:2862-6. doi:10.1210/ jcem.82.9.4247

68. Yasmeen S, Cress R, Romano PS, Xing G, Berger-Chen S, Danielsen B, et al. Thyroid cancer in pregnancy. Int J Gynaecol Obstet (2005) 91:15-20. doi:10.1016/j.ijgo.2005.06.022

69. Alves GV, Santin AP, Furlanetto TW. Prognosis of thyroid cancer related to pregnancy: a systematic review. J Thyroid Res (2011) 2011:691719. doi:10.4061/2011/691719

70. Glinoer D, Lemone M, Bourdoux P, De Nayer P, DeLange F, Kinthaert J, et al. Partial reversibility during late postpartum of thyroid abnormalities associated with pregnancy. J Clin Endocrinol Metab (1992) 74:453-7. doi:10.1210/ jcem.74.2.1730819

71. Rotondi M, Amato G, Biondi B, Mazziotti G, Del Buono A, Rotonda Nicchio M, et al. Parity as a thyroid size-determining factor in areas with moderate iodine deficiency. J Clin Endocrinol Metab (2000) 85:4534-7. doi:10.1210/ jcem.85.12.7002

72. del Senno L, degli Uberti E, Hanau S, Piva R, Rossi R, Trasforini G. In vitro effects of estrogen on tgb and c-myc gene expression in normal and neoplastic human thyroids. Mol Cell Endocrinol (1989) 63:67-74. doi:10.1016/ 0303-7207(89)90082-8
73. Furlanetto TW, Nguyen LQ, Jameson JL. Estradiol increases proliferation and down-regulates the sodium/iodide symporter gene in FRTL-5 cells. Endocrinology (1999) 140:5705-11. doi:10.1210/endo.140.12.7197

74. Manole D, Schildknecht B, Gosnell B, Adams E, Derwahl M. Estrogen promotes growth of human thyroid tumor cells by different molecular mechanisms. JClin Endocrinol Metab (2001) 86:1072-7. doi:10.1210/ jcem.86.3.7283

75. Banu SK, Govindarajulu P, Aruldhas MM. Testosterone and estradiol differentially regulate TSH-induced thyrocyte proliferation in immature and adult rats. Steroids (2002) 67:573-9. doi:10.1016/S0039-128X(02)00008-9

76. Zeng Q, Chen GG, Vlantis AC, van Hasselt CA. Oestrogen mediates the growth of human thyroid carcinoma cells via an oestrogen receptorERK pathway. Cell Prolif (2007) 40:921-35. doi:10.1111/j.1365-2184.2007. 00471.x

77. Rajoria S, Suriano R, Shanmugam A, Wilson YL, Schantz SP, Geliebter J, et al. Metastatic phenotype is regulated by estrogen in thyroid cells. Thyroid (2010) 20:33-41. doi:10.1089/thy.2009.0296

78. Rajoria A, Suriano R, George A, Shanmugam A, Schantz SP, Geliebter J, et al. Estrogen induced metastatic modulators MMP-2 and MMP-9 are targets of 3,3'-diindolylmethane in thyroid cancer. PLoS One (2011) 6:e15879. doi:10.1371/journal.pone.0015879

79. Dong W, Zhang H, Li J, Guan H, He L, Wang Z, et al. Estrogen induces metastatic potential of papillary thyroid cancer cells through estrogen receptor $\alpha$ and $\beta$. Int J Endocrinol (2013) 2013:941568. doi:10.1155/2013/941568

80. Vivacqua A, Bonofiglio D, Albanito L, Madeo A, Rago V, Carpino A, et al. $17 \beta$-Estradiol, genistein, and 4-hydroxytamoxifen induce the proliferation of thyroid cancer cells through the G protein-coupled receptor GPR30. Mol Pharmacol (2006) 70:1414-23. doi:10.1124/mol.106.026344

81. Chen GG, Vlantis AC, Zeng Q, van Hasselt CA. Regulation of cell growth by estrogen signaling and potential targets in thyroid cancer. Curr Cancer Drug Targets (2008) 8:367-77. doi:10.2174/156800908785133150

82. Santin AP, Furlanetto TW. Role of estrogen in thyroid function and growth regulation. J Thyroid Res (2011) 2011:875125. doi:10.4061/2011/875125

83. Di Vito M, De Santis E, Perrone GA, Mari E, Giordano MC, De Antoni E, et al. Overexpression of estrogen receptor- $\alpha$ in human papillary thyroid carcinomas studied by laser-capture microdissection and molecular biology. Cancer Sci (2011) 102:1921-7. doi:10.1111/j.1349-7006.2011.02017.x

84. Huang Y, Dong W, Li J, Zhang H, Shan Z, Teng W. Differential expression patterns and clinical significance of estrogen receptor- $\alpha$ and $\beta$ in papillary thyroid carcinoma. BMC Cancer (2014) 14:383. doi:10.1186/ 1471-2407-14-383

85. Magri F, Capelli V, Rotondi M, Leporati P, La Manna L, Ruggiero R, et al. Expression of estrogen and androgen receptors in differentiated thyroid cancer: an additional criterion to assess the patient's risk. Endocr Relat Cancer (2012) 19:463-71. doi:10.1530/ERC-11-0389

86. Vannucchi G, De Leo S, Perrino M, Rossi S, Delfina Tosi D, Cirello V, et al. Impact of estrogen and progesterone receptor expression on the clinical and molecular features of papillary thyroid cancer. Eur J Endocrinol (2015) 173:29-36. doi:10.1530/EJE-15-0054

87. Sturniolo G, Zafon C, Moleti M, Castellvi J, Vermiglio F, Mesa J. Immunohistochemical expression of estrogen receptor- $\alpha$ and progesterone receptor in patients with papillary thyroid carcinoma. Eur Thyroid J (2016) 5:224-30. doi:10.1159/000452488

88. Nielsen SM, White MG, Hong S, Aschebrook-Kilfoy B, Kaplan EL, Angelos P, et al. The breast-thyroid cancer link: a systematic review and meta-analysis. Cancer Epidemiol Biomarkers Prev (2016) 25:231-8. doi:10.1158/1055-9965. EPI-15-0833

89. Tan MH, Mester JL, Ngeow J, Rybicki LA, Orloff MS, Eng C. Lifetime cancer risks in individuals with germline PTEN mutations. Clin Cancer Res (2012) 18:400-7. doi:10.1158/1078-0432.CCR-11-2283

90. An JH, Hwangbo Y, Ahn HY, Keam B, Lee KE, Han W, et al. A possible association between thyroid cancer and breast cancer. Thyroid (2015) 25:1330-8. doi:10.1089/thy.2014.0561

91. Kuo JH, Chabot JA, Lee JA. Breast cancer in thyroid cancer survivors: an analysis of the surveillance, epidemiology, and end results-9 database. Surgery (2016) 159:23-9. doi:10.1016/j.surg.2015.10.009

92. Wang C, Mayer JA, Mazumdar A, Brown PH. The rearranged during transfection/papillary thyroid carcinoma tyrosine kinase is an estrogendependent gene required for the growth of estrogen receptor positive breast 
cancer cells. Breast Cancer Res Treat (2012) 133:487-500. doi:10.1007/ s10549-011-1775-9

93. Mulligan LM. RET revisited: expanding the oncogenic portfolio. Nat Rev Cancer (2014) 14:173-86. doi:10.1038/nrc3680

94. Romei C, Ciampi R, Elisei R. A comprehensive overview of the role of the RET proto-oncogene in thyroid carcinoma. Nat Rev Endocrinol (2016) 12:192-202. doi:10.1038/nrendo.2016.11

95. Forbes K, Westwood M. Maternal growth factor regulation of human placental development and fetal growth. J Endocrinol (2010) 207:1-16. doi:10.1677/ JOE-10-0174
Conflict of Interest Statement: The authors declare that the research was conducted in the absence of any commercial or financial relationships that could be construed as a potential conflict of interest.

Copyright (๔ 2017 Moleti, Sturniolo, Di Mauro, Russo and Vermiglio. This is an open-access article distributed under the terms of the Creative Commons Attribution License (CC BY). The use, distribution or reproduction in other forums is permitted, provided the original author(s) or licensor are credited and that the original publication in this journal is cited, in accordance with accepted academic practice. No use, distribution or reproduction is permitted which does not comply with these terms. 